\title{
The Legal Regulation of Non-stun Slaughter: Balancing Religious Freedom, Non-discrimination and Animal Welfare
}

\author{
Joe Wills ${ }^{1}$
}

Published online: 28 May 2020

(c) The Author(s) 2020

\begin{abstract}
In February 2019, The Royal Society for the Prevention of Cruelty to Animals (RSPCA) and the British Veterinary Association (BVA) published a joint open letter to the British Government calling for a repeal of a legal exemption that permits the slaughter of animals without prior stunning. The RSPCA and BVA argue that repealing the exemption is required on grounds of animal welfare, claiming that non-stun slaughter causes unnecessary pain and suffering. By contrast, Islamic and Jewish groups assert that non-stun slaughter, when properly conducted, is both humane and a religious requirement for least some followers of their faiths. This article considers whether imposing a ban on non-stun slaughter is compatible with obligations to protect religious freedom and non-discrimination under the European Convention of Human Rights. It will conclude that it can be and, when done to protect animal welfare, falls within Contracting States' margin of appreciation.
\end{abstract}

Keywords Human rights $\cdot$ Freedom of religion $\cdot$ Non-discrimination $\cdot$ Animal welfare

\section{Introduction}

In February 2019, The Royal Society for the Prevention of Cruelty to Animals (RSPCA) and the British Veterinary Association (BVA) published a joint open letter to the British Government calling for a repeal of a legal exemption that permits the slaughter of animals without prior stunning (BVA 2019). Standardly, animals who are slaughtered are required to be rendered unconscious prior to being killed, but

Joe Wills

jjw24@1e.ac.uk

1 University of Leicester, University Rd, Leicester LE1 7RH, UK 
an exception is carved out for a certain proportion of followers of the Jewish and Islamic faiths who interpret their religious scripture as requiring that animals killed for food are fully conscious at the time. ${ }^{1}$

The RSPCA and BVA argue that repealing the exemption is required on grounds of animal welfare, claiming that non-stun slaughter causes unnecessary pain and suffering. By contrast, Islamic and Jewish groups assert that non-stun slaughter, when properly conducted, is both humane and a religious requirement for least some followers of their faiths (Zivotofsky 2012; Muslim Council of Britain 2015; Millis 2019).

This division between religious communities and animal welfare advocates is being witnessed across Europe. Twelve countries have either banned non-stun slaughter or placed restrictions on it, justifying these measures on grounds of animal welfare (Law Library of Congress 2018, p. 20). Religious groups have bought legal challenges against these bans on the basis that they are incompatible with freedom of religion. In Poland in 2014, the Association of Jewish Religious Communities succeeded in their application to have a ban on non-stun slaughter declared unconstitutional by the Polish Constitutional Tribunal. ${ }^{2}$ In Belgium, the Belgian Federation of Jewish Organisations have issued a legal challenge to the prohibition on non-stun slaughter in the Flanders region. Belgium's Constitutional Court has referred the matter to the European Court of Justice for a non-binding judgement (Wax 2019).

This dispute between mainstream animal welfare groups and religious groups over the acceptability of non-stun slaughter is unlikely to be resolved any time soon. Indeed, questions around the legal regulation of non-stun slaughter are also intertwined with issues around identity and how minority practices ought to be accommodated in a multicultural democracy. This article does not delve into these delicate political issues. ${ }^{3}$ Instead, its focus will be on the narrower question of how these competing concerns relating to religious freedom, non-discrimination and animal welfare would likely be resolved in the legal human rights framework of the European Convention of Human Rights (ECHR). Drawing on the jurisprudence of the European Court of Human Rights (ECtHR) and other relevant Strasbourg organs and international law principles, this article will conclude that whilst non-stun slaughter bans do interfere with article 9 of the ECHR (freedom to manifest religious beliefs) as well as article 14 (non-discrimination in the enjoyment of ECtHR rights), they do

\footnotetext{
1 The Welfare of Animals at the Time of Killing (England) Regulations 2015 SI 2015/1782, Schedules 1-3. It is important to bear in mind that, in the UK, the majority of Muslims and Jews do not observe the requirement to consume non-stun slaughter meat. The majority of animals slaughtered for the production of halal meat are pre-stunned (DEFRA 11 2019). Although all animals killed for the production of Jewish Kosher meat are unstunned, surveys reveal that, excluding Jewish vegetarians and vegans, over half of UK Jews purchase non-kosher meat for the home and 64\% purchase it outside of the home (Institute for Jewish Policy Research 2014, p. 7).

2 Judgment of 10 Dec. 2014, Ref. No. K52/13.

3 This author's own view is that animal protection organisations would be well advised to prioritise animal welfare campaigns other than non-stun slaughter. There are many more widespread welfare concerns associated with, e.g. industrialised animal agriculture to address that do not involve the sensitive minority group issues that non-stun slaughter does. This is, however, a separate issue to whether non-stun slaughter bans amount to violations of human rights.
} 
not necessarily violate them, because they can fall within States' a margin of appreciation to protect animal welfare.

The article proceeds as follows. Section "European Animal Welfare Law and Non-stun Slaughter" lays out the European welfare regimes governing non-stun slaughter, then section "Religious Slaughter and the ECHR" argues that non-stun slaughter falls within the scope of article 9 of the ECtHR. Section "Limiting Religious Freedom" considers whether a ban on non-stun slaughter on animal welfare grounds could be justified under article 9(2). It argues that such a restriction could be justified on the basis of the 'protection of morals' and possibly on the basis of protecting 'the rights and freedoms of others'. This analysis is continued in section "Margin of Appreciation: Narrow or Wide?", which considers whether Contracting Parties are likely to have a wide or narrow margin of appreciation with respect to bans on non-stun slaughter. It will conclude that States are likely to be given a wide margin of appreciation on this issue, but even under a narrower margin it will be relatively easy for Contracting Parties to demonstrate that such bans are necessary in a democratic society and therefore not in violation of article 9. Finally, section "Non-stun Slaughter and Discrimination" considers whether a non-stun slaughter ban could constitute discrimination under article 14 (in conjunction with article 9). It concludes that, whilst these bans do constitute a form of indirect discrimination, they are not in breach of article 14 because they pursue a legitimate aim and there is a reasonable relationship of proportionality between that aim and the means of a total ban on non-stun slaughter.

\section{European Animal Welfare Law and Non-stun Slaughter}

Before considering the issues of religious freedom and non-discrimination, it is useful to begin by considering the present legal regimes relating to the slaughter of animals in Europe.

There are two treaties regulating slaughter at the regional European level. The first is the Council of Europe's (CoE) European Convention for the Protection of Animals for Slaughter. ${ }^{4}$ This requires that animals 'shall be stunned by an appropriate method" ${ }^{5}$ but permits Contracting Parties to authorise derogations from this requirement where, inter alia, the slaughtering is 'in accordance with religious rituals' ${ }^{6}$ It is important to note that whilst the Convention permits such derogation, it does not require it, thereby leaving discretion to Contracting Parties to determine the balance they wish to strike between considerations of religious freedom and animal welfare.

The second relevant treaty is the European Union's Council Regulation $1099 / 2009$ on the protection of animals at the time of killing. ${ }^{7}$ This Regulation

\footnotetext{
4 Strasbourg (1979) ETS No.102).

5 ibid, art. 12 .

6 ibid, art. 17.

7 OJ L 303/1.
} 
requires that animals are either instantaneously killed ('simple stunning') or stunned prior to killing so that there is loss of consciousness and sensibility at the time of death. ${ }^{8}$ The recitals to the Regulation make clear that animal welfare is a Community value, enshrined in EU law. ${ }^{9}$ It recognises that many killing methods are painful for animals and, consequently, that stunning is 'necessary to induce a lack of consciousness and sensibility before, or at the same time as, the animals are killed'10 to 'avoid pain and minimise the distress and suffering of animals'. ${ }^{11}$ Though minimum requirements for slaughter are established in the Regulation, Member States can adopt national rules that provide more extensive protections of animals at the time of killing. ${ }^{12}$

Like the CoE Convention, the EU Regulation also permits an exemption on the requirement for pre-stunning when the method of killing is 'prescribed by religious rites' ${ }^{13}$ The recitals recall that an earlier Directive regulating slaughter permitted derogation from stunning in the case of religious slaughter and that this is maintained in Regulation 1099/2009 because 'Community provisions applicable to religious slaughter have been transposed differently depending on national contexts'. ${ }^{14}$ Derogation from the requirement of pre-stunning allows both 'a certain level of subsidiarity to each Member State' and 'respects the freedom of religion'. ${ }^{15}$ This subsidiarity in relation to religious slaughter is further reflected in article 26(2)(c) which permits Member States to adopt national rules aimed at ensuring more extensive protection of animals at the time of killing where the killing is done is accordance with religious slaughter.

In summary, both the $\mathrm{CoE}$ and EU treaties provide that animals should be stunned before they are slaughtered but also provide that States may allow derogations from this requirement to for ritual slaughter. We will now consider how the issue of religious non-stun slaughter relates to international human rights law.

\section{Religious Slaughter and the ECHR}

\section{Freedom of Religion Under Article 9}

Article 9(1) of the European Convention on Human Rights and Fundamental Freedoms (ECHR) states that 'Everyone has the right to freedom of thought, conscience and religion'. This includes the right to manifest religion through 'worship, teaching, practice and observance'. Article 9(1) thus distinguishes between two dimensions of freedom of religion; the holding of religious beliefs ('forum internum') and religious

\footnotetext{
${ }^{8}$ Ibid art. 4(1) and annex 1.

9 Ibid, rec. 4.

10 Ibid, rec. 20.

11 Ibid, rec. 2.

12 Ibid, art. 26(1).

13 Ibid, art. 4(4).

14 Ibid, rec. 18.

15 Ibid.
} 
belief externally manifested through practice ('forum externum'). ${ }^{16}$ The forum internum is absolute and unconditional; the State cannot interfere with it under any circumstances. By contrast, the forum externum is not absolute; since the manifestation of a person's religious beliefs can have an impact on others, this aspect of the right is qualified. Under article 9(2), freedom to manifest religious beliefs may be interfered with provided that such limitations are prescribed by law, pursue a legitimate aim and are necessary in a democratic society.

In the past, the scope of article 9 has been construed narrowly. In Arrowsmith $v$ United Kingdom ${ }^{17}$ the former European Commission on Human Rights held that only manifestations of a person's religion or belief that are mandated by those belief systems are protected by article 9 (para 3). This restrictive interpretation of the right meant that article 9 protection did not extend to non-mandatory religious practice. The European Court of Human Rights broke with this approach in Eweida $v$ United Kingdom, stating that 'there is no requirement on the applicant to establish that he or she acted in fulfilment of a duty mandated by the religion in question'. Instead the act in question 'must be intimately linked to the religion or belief' ${ }^{18}$

\section{Article 9 and Religious Slaughter}

Do practices of religious slaughter fall within the scope of the article 9? This was the question the Strasbourg Court adjudicated in Cha'are Shalom Ve Tsedek v France. ${ }^{19}$ The applicants in that case were an ultra-orthodox Jewish association who were unsatisfied with the methods of shechita slaughter approved by the Jewish Consistorial Association of Paris, an organisation representing the majority of practicing Jews in France. Consequently, they applied to the national authorities to grant them the requisite approval to authorise their own slaughterers to perform in accordance with their stricter standards. The French authorities refused to grant their application and the applicants maintained that this was refusal was in breach of article 9 .

The Grand Chamber of the Strasbourg Court dismissed the application by 12 votes to 5 . The majority took the view that there had been no interference with freedom to manifest religious beliefs under article 9 because the scope of that right does not extend to "the right to take part in person in the performance of ritual slaughter and the subsequent certification process' ${ }^{20}$ The majority did however find that the prohibition on performing the ritual slaughter would have amounted to an interference with article 9 if it made it impossible for the applicants to access meat slaughtered in accordance with their religious prescriptions ('glatt'). However, because the applicant association could easily obtain supplies of glatt meat from Belgium, that

\footnotetext{
${ }^{16}$ C. $v$. the United Kingdom, Application No. 10358/83; Nolan and $K v$ Russia, Application No. 2512/05, para 59.

17 Application No. 7050/75.

18 Application No. 48420/10, para 82.

19 Application No. 27417/95.

20 Ibid, para 82.
} 
consideration did not arise in the case at hand. ${ }^{21}$ The minority took the view that the practice of one's religion through performance of the rite of ritual slaughter does constitute part of the freedom of religion and whether or not the applicant association had access to glatt meat was irrelevant to the question of whether or not there had been an interference under article $9 .^{22}$

The decision of the Grand Chamber majority in Cha'are Shalom Ve Tsedek has been criticised by several commentators for construing the scope of article 9 too narrowly and failing to engage in appropriate discrimination analysis (Haupt 2007, p. 885; Cohen 2009, p. 375; Henrard 2016, p. 970). Whilst this author agrees that the reasoning of the Grand Chamber majority in Cha'are Shalom Ve Tsedek was rather laconic, the conclusion it arrived at is arguably doctrinally consistent with the Court's interpretation of the scope of article 9 at the time. As noted above, in Arrowsmith $v$ United Kingdom it was determined that the scope of article 9 covered only manifestations of a person's religion or belief that are mandated by those belief systems. As it is plainly not the case that ultra-orthodox Judaism mandates any particular Jewish individual or organisation to personally authorise or take part in ritual slaughter, that aspect of manifestation of religious belief is not covered by article 9 .

Whilst the outcome in Cha'are Shalom Ve Tsedek was doctrinally consistent with the broader Strasbourg case law of its time, there is reason to doubt that the same decision would be correct today. This is because since Eweida v United Kingdom, the scope of article 9(1) has been interpreted more broadly to include all acts that are 'intimately linked to the religion or belief'. ${ }^{23}$ It seems undeniable that ritual slaughter is intimately linked to the religious doctrines that require them.

Furthermore, ritual slaughter is understood as part of freedom of religion under other regimes of international law, including EU law. In Liga van Moskeeën en Islamitsche Organisaties Provincie Antwerpen VZW and Others v Vlaams Gewest the European Court of Justice (ECJ) stated that ritual slaughter falls within the scope of the freedom of religion guaranteed by the Charter of Fundamental Rights of the European Union. ${ }^{24}$ It further added that 'Possible theological differences on that subject cannot in themselves invalidate that classification as a "religious rite". 25 In Cuvre d'assistance aux bêtes d'abattoirs (OABA) v Ministre de l'Agriculture et de l'Alimentation, Bionoor, Ecocert France, Institut national de l'origine et de la qualité the ECJ further clarified that the derogation on the need for prior-stunning in cases of religious slaughter exists 'solely in order to ensure observation of freedom of religion'. ${ }^{26}$

\footnotetext{
21 Ibid, para 81.

22 Ibid, Joint Dissenting Opinion of Judges Bratza, Fischbach, Thomassen, Tsata-Nikolovska, Pantiru, Levits and Traja, para 2.

23 N 17, para 82.

${ }^{24}$ Case C-426/16, para 49.

25 Ibid, para 51.

26 Case C-497/17, para 48.
} 
Whilst EU law is not binding on the Strasbourg Court, it can take be taken into account. As the Grand Chamber noted in Demir and Baykara v Turkey, it 'has never considered the provisions of the Convention as the sole framework of reference for the interpretation of the rights and freedoms therein' ${ }^{27}$ and furthermore:

in defining the meaning of terms and notions in the text of the Convention, it can and must take into account elements of international law other than the Convention, the interpretation of such elements by competent organs, and the practice of European States reflecting their common values. ${ }^{28}$

Accordingly, it is common practice for the Strasbourg Court to cite relevant provisions of the Charter of Fundamental Rights of the European Union (CFREU), instruments of European Union secondary legislation and rulings of the Court of Justice of the European Union (ECJ) in considering the evolving scope of Convention rights. ${ }^{29}$ The fact the ECJ has interpreted religious slaughter as being part of freedom of religion as protected under article 10 of the CFREU could therefore be considered by the Strasbourg court in determining the scope of article 9.

In summary, it is argued that the Grand Chamber's finding in Cha'are Shalom Ve Tsedek that religious slaughter is not protected under article 9 is untenable today. Following the Eweida ruling, the Court now interprets the scope of article 9 much more broadly than it did when it heard Cha'are Shalom Ve Tsedek. Moreover, the ECJ has also subsequently recognised religious slaughter as forming part of religious freedom under the CFREU, evidencing an 'evolving convergence' on the matter. Consequently, the Strasbourg Court can no longer tenably assert that religious slaughter falls out of the scope of article 9. Instead, the analysis ought to shift to the question of whether banning non-stun slaughter can be justified under article 9(2). We turn to that question in the next section.

\section{Limiting Religious Freedom}

If religious slaughter is included within article 9, introducing a ban on non-slaughter that would have the effect of prohibiting certain types of religious slaughter could only be lawful if it was justified under article 9(2) requiring it to be prescribed by law, pursue a legitimate aim and be necessary in a democratic society. We will now consider each of these requirements in turn.

\footnotetext{
27 Application no. 34503/97, para 85.

28 Ibid.

29 See e.g.; Micallef $v$ Malta, Application no. 17056/06, paras 32 and 78; Vinters and Others $v$ United Kingdom, Applications nos. 66069/09, 130/10 and 3896/10, para 67; Jeunesse $v$ The Netherlands, Application no. 12738/10, paras 69-72; M.S.S. v. Belgium and Greece, Application no. 30696/09, paras 57-86; Tarakhel $v$ Switzerland, Application no. 29217/12 paras 28-35.
} 


\section{Prescribed by Law}

A restriction on a right must be prescribed by law to constitute a legitimate interference. Four essential components are required to satisfy this test. First, the domestic legal system must sanction the interference. ${ }^{30}$ Second, the law must be adequately accessible to citizens, meaning that they 'must be able to have an indication that is adequate in the circumstances of the legal rules applicable to a given case'. ${ }^{31}$ Third, the law must be formulated with sufficient precision to enable citizens to foresee the exact scope and meaning of the provision, including 'the consequences a given action may entail' ${ }^{32}$ Finally, there must be adequate safeguards against arbitrary interference with the affected substantive rights. ${ }^{33}$

As banning non-stun slaughter would involve merely retracting a derogation, and bringing all slaughter of animals within the same, well established regulatory framework, establishing such a ban is unlikely to raise any rule of law issues so we can swiftly move on to the next consideration.

\section{Pursues a Legitimate Aim}

Article 9(2) enumerates five different legitimate aims that can justify interferences with religious freedom: the interests of public safety; the protection of public order, the protection of health, the protection of morals; and the protection of the rights and freedoms of others.

In Cha'are Shalom Ve Tsedek, the Grand Chamber majority held that restricting the ability to participate in religious slaughter could be justified on the basis that it pursues the legitimate aims of 'protection of public health and public order'. This claim was justified on the basis that 'organisation by the State of the exercise of worship is conducive to religious harmony and tolerance'. ${ }^{34}$

It is unclear how this aim relates to public health. As the minority observe, 'there is nothing to suggest that the ritual slaughterers employed by the applicant association do not comply... with the rules of hygiene'. ${ }^{35}$ The appeal to public order is equally unconvincing. There was no evidence adduced in Cha'are Shalom Ve Tsedek that granting the applicants the ability to approve their own slaughterers would have had any effect of undermining religious harmony and tolerance. On the whole then, protection of public order and health appear to be weak bases for interfering with religious freedom with respect to religious slaughter.

The more relevant legitimate aims to consider in relation to restricting certain methods of religious slaughter on animal welfare grounds are the protection of

${ }^{30}$ Kruslin v France, Application no. 11801/85, para 27.

31 Sunday Times $v$ The United Kingdom (No. 1), Application no. 6538/74, para 49.

32 Ibid.

33 Söderman v Sweden, Application no. 5786/08, para 83.

34 Cha'are Shalom (n 18), para 84.

35 Joint Dissenting Opinion, para 2. 
morals and the protection of the rights and freedoms of others. We shall now examine each of these.

\section{Protection of Morals}

The stated motivation of governments and organisations who support a ban on nonstun slaughter is to limit the suffering of animals at the time of killing. It is undoubtable that concern for the wellbeing of animals is part of public morality across Europe (Zoethout 2013). A survey requested by the European Commission in 2015 found that more than nine in ten EU citizens believe it is important to protect the welfare of farmed animals, with $82 \%$ believing they should receive better protection than they currently do and $74 \%$ believed similarly with respect to companion animals (EU 2016).

Moreover, the Strasbourg Court itself has recognised that protecting animal welfare can justify limiting a right on the basis protecting morals. In Friend \& Others $v$ United Kingdom, ${ }^{36}$ the ECtHR found that measures taken by the UK Government to ban hunting mammals with dogs pursued the legitimate aim of the protection of morals:

in the sense that they were designed to eliminate the hunting and killing of animals for sport in a manner which the legislature judged to cause suffering and to be morally and ethically objectionable. ${ }^{37}$

One could make a parallel argument with respect to a ban on non-stun slaughter; laws put in place to prohibit slaughter without prior stunning serve to eliminate methods of slaughter that the legislature judges to cause suffering and to be morally and ethically objectionable.

However, although protection of morals is a legitimate aim that can justify restricting freedom of religion under article 9(2), Member States tend not to appeal to this, instead preferring the protection of public order and the rights freedoms of others as the basis for justifying restrictions on religious freedom (Evans 2001, p. 160). The reason is surely obvious; religions themselves are sources of morality, yet, in secular, multicultural and multi-faith societies there is no one 'official' religion or interpretation of religion that provides the basis for a common shared morality. Allowing the morality of one religion or belief system to predominate over others carries significant risks of authoritarianism and stands in contrast to the ECtHR's stated commitment to 'pluralism, tolerance and broad mindedness' ${ }^{38}$ It is for this reason that the UN Human Rights Council have warned that 'limitations on the right to manifest a religion or belief for the purposes of protecting morals must be based on principles not deriving exclusively from a single tradition'. ${ }^{39}$

\footnotetext{
36 Applications nos. 16072/06 and 27809/08.

37 Ibid, para 50.

38 Handyside v The United Kingdom, Application no. 5493/72, para 49.

39 UN Human Rights Committee. CCPR General Comment No. 22: Article 18 (Freedom of Thought, Conscience or Religion), 30 July 1993, CCPR/C/21/Rev.1/Add.4, para 8.
} 
Yet concerns about preserving ethical pluralism are arguably less applicable to the issue of restricting non-stun slaughter on animal welfare grounds. Protecting animal welfare and minimising animal suffering are not ethical imperatives confined to a single faith or culture. Care and compassion for other species is a cross-cultural, cross-faith — and possibly even a universal — value reflected in a broad range of legal systems and shared by diverse communities and belief systems, including Judaism and Islam (Bowman et al. 2010, pp. 672-699). Indeed, defenders of non-stun slaughter themselves do not defend the practice because, or despite the fact that, it causes unnecessary suffering. To the contrary, they maintain that non-stun slaughter, when done correctly, actually causes no more suffering to animals than alternative methods, and perhaps even less (Lerner and Rabello 2006, p. 48). In other words, the dispute about animal suffering and non-stun slaughter is primarily empirical rather than normative in nature. In a liberal, multicultural society, the State ought to permit a plurality of ethical practices, but it is under no obligation to abstain from instituting evidence-based legislation aimed at upholding common moral values in the face of epistemic disagreement about the relevant facts.

Undoubtedly, many religious individuals would still maintain that non-stun slaughter serves important moral principles other than those pertaining to animal welfare. A pluralist can accept that religious practices do serve important moral purposes for the communities who practice them and it would not be appropriate to restrict or ban such practices purely on the basis that they conflict with the moral values of another tradition, even if that tradition is the majority. However, where the basis of the objection is that the practice in question is contrary to common moral values, restricting such practices is less of an affront to pluralist values.

\section{Protection of the Rights and Freedoms of Others}

The Strasbourg Court often cites the "protection of the rights and freedoms of others' as one of the legitimate aims a State pursues in interfering with freedom of religion (Evans 2001, pp. 161-164). A number of commentators have noted that the Court typically fails to spell out with precision who constitute the relevant 'others' and which of their 'rights' or 'freedoms' have been interfered with. Consequently, the phrase has been described as 'something of a catchall' (Evans 1997, p. 328) that the Strasbourg organs have invoked in a 'perfunctory' (Schabas 2015, p. 437) and 'highly casuistic' manner (Greer 1997, p. 35).

At the very least, it is evident that the Court has interpreted the phrase as protecting a range of rights and freedoms that are significantly broader than enumerated in the ECHR and its protocols. A few examples will suffice to illustrate. In ISKCON and others $v U K,{ }^{40}$ restrictions on planning laws to a Hindu place of worship were justified in part by reference to the rights and freedoms of those who lived in the nearby village. In Leyla Sahin v Turkey, ${ }^{41}$ a headscarf ban in public universities was justified by an offhand reference to public order and the rights and freedoms of

\footnotetext{
40 Application no. 20490/92.

41 Application no. 44774/98.
} 
others. In $S A S v$ France, ${ }^{42}$ a ban on wearing the full face veil ('niqab') was found to pursue the legitimate aim of protecting the rights and freedoms of others because the veil was 'perceived by the respondent State as breaching the right of others to live in a space of socialisation which makes living together easier'. ${ }^{43}$

In light of the above, perhaps we can say that banning non-stun slaughter could be justified based on protecting the right of people to live in a society in which there are laws protecting animals against unnecessary suffering. Whilst this line of argument is possible given how broadly the Strasbourg organs have construed this legitimate aim, it is perhaps a bridge too far because such a 'right' has no obvious or direct connection to the interests that people have, other than their interests of living in a particular type of society. Interests of this type are so broad that allowing them to constitute rights or freedoms that can justify restrictions of religion could make the notion of a legitimate aim under article 9(2) so open-ended as to be entirely meaningless.

An alternative line of argument would be that a ban on non-stun slaughter could be justified to protect the rights and freedoms of the animals themselves. This would for sure be a novel argument in the context of the ECHR, but not one lacking merit. Whilst it is unlikely that the drafters of the ECHR had nonhuman animals in mind when they drafted the phrase 'rights and freedoms of others', the Court has repeatedly affirmed that the Convention is a 'living instrument which... must be interpreted in light of present-day conditions'. ${ }^{4}$

It is undeniable that the moral, political and legal landscape with regard to nonhuman animals has shifted dramatically since 1953. In his separate judgement in Herrmann v Germany, Judge Pinto De Albuquerque argues that there is 'clear and uncontested evidence of a continuing international trend' in the practice of European States that is 'in favour of the protection of animal life and welfare'. This, Judge Albuquerque says, is 'reflected in the application of the Convention'. ${ }^{45}$

This international trend can be evidenced through, inter alia:

1. the overturning of animals' status as 'things' (res) in European civil law jurisdictions (Peters 2017);

2. the recognition of animals as 'sentient beings' at the regional, State and supranational levels across Europe (Blattner 2019);

3. animals being afforded constitutional protection in $5 \mathrm{CoE}$ states (Eisen 2017);

4. a considerable body of international animal welfare law developed by the Council of Europe and the EU (Global Animal Law);

5. animal welfare constituting 'a legitimate objective in the public interest' under EU law; ${ }^{46}$

\footnotetext{
${ }^{42}$ Application no. 43835/11.

${ }^{43}$ Ibid, para 122.

${ }^{44}$ Tyrer $v$ The United Kingdom, Application no. 58556/72, para 31.

45 Application no 9300/07, Partly concurring and partly dissenting opinion of Justice Pinto De Albuquerque.

${ }^{46}$ Zuchtvieh-Export GmbH v. Stadt Kempten, Case C-424/13, para 35.
} 
6. the EU prohibitions on the trade in cosmetics tested on animals, ${ }^{47}$ seal products ${ }^{48}$ and cetacean products, ${ }^{49}$ on animal welfare grounds.

These developments together constitute powerful evidence of a continuing international trend that recognises that sentient animals ought to be afforded legal protection for their own sakes. Accordingly, the legal duties human beings are placed under in relation to animal welfare ought to be understood as the correlate of animal legal claim-rights to have their welfare protected. ${ }^{50}$ Thus, prohibiting non-stun slaughter on animal welfare grounds is best understood as bestowing a legal right on animals not to be slaughtered without prior stunning.

But ought animals be regarded as 'others' whose rights and freedoms constitute a legitimate aim that can justify restricting Convention rights? According to Judge Albuquerque: 'Under the Convention, "animal rights"... correspond to obligations imposed on the Contracting Parties as part of their commitment to full, effective and practical enjoyment of human rights'. ${ }^{51}$ This entails that 'the safeguarding of the environment and animal life constitutes an implicit restriction on the exercise of human rights' and is 'an inherent obligation on the Contracting Parties bound by the Convention'. ${ }^{52}$ The most direct way for the Strasbourg Court to allow States to place restrictions on Convention rights in order to protect animal rights is to recognise that non-human animals can be 'others' in the relevant sense for the introduction of human rights-restricting legislation aimed at protecting animal interests. This non-anthropocentric reading of the 'rights and freedoms of others' legitimate aim is warranted in light of the clear international trend across Europe in recognising as animals as possessing intrinsic value in need of legal protection. However, notwithstanding the preceding argument, given that framing a legitimate aim in terms of the rights and freedoms of animals would be a novel claim, the article will proceed on the assumption that the legitimate aim under consideration here is the protection of morals.

\section{Necessary in a Democratic Society}

The final limb of article $9(2)$ to satisfy is that the interference is 'necessary in a democratic society'. In Sunday Times $v$ The United Kingdom, ${ }^{53}$ the Court defined this term to mean:

\footnotetext{
47 Regulation (EC) No 1223/2009.

48 Regulation (EC) No 1007/2009.

49 Regulation (EC) No 348/81.

50 There is not space to develop this claim in this article, but it has been made compellingly elsewhere. See for example: Feinberg (1992, p.159), Sunstein (2000, p. 47) and Bilchitz (2009, p. 43).

51 Herrmann v Germany (n 45), Partly concurring and partly dissenting opinion of Justice Pinto De Albuquerque.

52 Ibid.

53 Sunday Times $v$ The United Kingdom (n 29).
} 
It must... be decided whether the "interference" complained of corresponded to a "pressing social need," whether it was "proportionate to the legitimate aim pursued," [and] whether the reasons given by the national authorities to justify it are "relevant and sufficient". 54

There are three normative components residing in the phrase 'necessary in a democratic society': (1) corresponding to a pressing social need; (2) proportionate to the legitimate aim pursued and; (3) accompanied by 'relevant and sufficient' reasons. Let's consider these in turn.

\section{Pressing Social Need}

The notion of a 'pressing social need' is not defined in the Court's jurisprudence, but the phrase suggests that there ought to be a 'weight and importance' to the aims pursued (Gerards 2013, p. 467). It is not enough that 'the interests served by a limitation of a Convention right are legitimate, they should also be "pressing." (ibid). Moreover, implicit in the idea that the interference must 'correspond' to the aim is some requirement of effectiveness or appropriateness.

Are the animal welfare concerns relating to non-stun slaughter a pressing social concern? The ECtHR have noted that animal protection is a significant area of deliberation across Europe, pointing out that 'it cannot be denied that in many European societies there was, and is, an ongoing general debate on the protection of animals and the manner in which they are reared'. 55

The court has recognised the significance of such concerns in relation to the killing of animals on a number of occasions. In an article 10 case relating to the media's ability to report on the controversial practice of skinning seals alive, the Grand Chamber described the matter as a 'vital public interest'. ${ }^{56}$ In Friend \& Others $v$ The United Kingdom the Court found evidence relating to animal suffering was sufficient to ground a "public interest to ban hunting' ${ }^{57}$ The Grand Chamber has also acknowledged that objections to hunting have the required level of 'cogency, cohesion and importance' to be 'worthy of respect in a democratic society'. ${ }^{58}$ This should be sufficient to demonstrate that addressing welfare concerns relating to the killing of animals meets the threshold of a 'pressing social need'.

Would a prohibition on non-stun slaughter 'correspond' to this pressing social need? The straightforward answer to this is yes. In 2004, a report from the European Food Safety Authority concluded that 'due to the serious animal welfare concerns associated with slaughter without stunning, pre-cut stunning should always be performed' (EFSA 2004, p. 2). Moreover, the British Veterinary Association, the Federation of Veterinarians of Europe, the Farm Animal Welfare Committee, the Human Slaughter Association and the RSPCA are all against slaughter without pre-stunning

\footnotetext{
54 Ibid, para 62.

55 Verein gegen Tierfabriken v. Switzerland, Application no.24699/94, para 70.

56 Bladet Troms $\phi$ and Stensaas v. Norway, Application no.21980/93, para 73.

57 Friend \& Others $v$ United Kingdom (n 36), para 56.

58 Hermann v Germany, (n 42), para 20.
} 
because they believe that the scientific evidence shows that it causes unnecessary suffering (Downing 2015, p. 13). A recent ECJ ruling concluded, after surveying the evidence, that non-stun slaughter techniques are 'insufficient to remove all of the animal's pain, distress and suffering as effectively as slaughter with pre-stunning., ${ }^{59}$ These views are also supported by scientific studies (Mellor et al. 2009; Barrasso et al. 2020). Whilst there is not universal consensus on this claim (Grandin and Regenstein 1994), it is widely shared enough to establish a sufficient nexus between the need to address animal welfare and the prohibition of non-stun slaughter.

\section{Proportionate to the Legitimate Aim Pursued}

In determining if an interference is 'proportionate' the Court examines whether 'the disadvantage suffered by the applicant is excessive in relation to the legitimate aim pursued'. ${ }^{60}$ Such assessment is far from easy. After all, how is one supposed to objectively weigh, with any real precision, such seemingly heterogeneous values such as the disadvantage of not being able to participate in religious slaughter versus the benefit of protecting public concerns about animal welfare or the rights and freedom of animals to be spared unnecessary suffering?

It is important to note that when it comes to accessing the proportionality of an interference with a right, the Convention does not impose uniform rules for Contracting States. The Court has held that national authorities are generally better placed than a supranational tribunal to achieve the appropriate balance between the competing interests of the community and the protection of the fundamental rights of the individual. ${ }^{61}$ Instead, the Court affords a certain 'margin of appreciation' to national authorities, granting them a degree of latitude once the appropriate level of review has been decided by the court. ${ }^{62}$ The margin granted to a state can vary from very narrow to exceedingly wide, depending on the particular issues at play in the case. Whether a narrow or wide margin of appreciation would be applicable to a prohibition on non-stun slaughter requires significant analysis that will be reserved for the next section.

However, at this stage it is worth addressing the preliminary matter of whether a ban on non-stun slaughter would have any positive impact on animal welfare at all. Two claims have been advanced which contest the efficacy of non-stun slaughter bans in advancing welfare. The first is that non-stun slaughter causes no more suffering than other methods of killing animals for food. On this view, prohibiting nonstun slaughter would simply result in one method of animal slaughter that causes suffering to be replaced with another that is just as severe. In the ECJ case of Liga van Moskeeën, the Advocate General argued the following in his Opinion:

\footnotetext{
59 OABA v Ministre de l'Agriculture et de l'Alimentation (n 26), para 48.

${ }^{60}$ National Union of Belgian Police v Belgium, Application no.4464/70, para 49.

61 Handyside v. the United Kingdom (n 38), para 48.

62 ibid, para 49.
} 
There is nothing to rule out the possibility that slaughtering without stunning, carried out in proper circumstances, will be less painful for the animal than slaughtering the animal after stunning it in circumstances in which, for obvious reasons of profitability, and given the widespread industrialisation of the production of food of animal origin, the stress and suffering experienced by the animal when it is killed are exacerbated. ${ }^{63}$

Critiquing this line of argument, Anne Peters notes that the Advocate General is not comparing like with like. The relevant comparison is not between non-stun slaughter under ideal conditions and pre-stun slaughter under existing conditions. Rather, one ought to contrast both methods as subject to the same 'worldly' pressures of industrialisation and economic profitability. All else equal, the 'two types of slaughter practices (stunned and un-stunned) are not identical in their effect on animal welfare. Veterinarians agree that stunning is better for the animals' (Peters 2019, pp. 20-21).

Perhaps a stronger version of the argument that non-stun slaughter causes no more suffering than conventional methods is that the methods of pre-stunning animals themselves are little or no better than the non-stun method. As the Polish Constitutional Tribunal noted: 'it is too often overlooked that the current law also permits various methods of animal slaughter with prior stunning which inevitably induce suffering, pain and distress to animals' ${ }^{64}$ Methods such as the $\mathrm{CO}_{2}$ asphyxiation of pigs and electrically stunning of chickens are well documenting as causing significant suffering (Gregory 1996; Shields and Raj 2010).

The near ubiquity of suffering in both the rearing and slaughter of farm animals undoubtedly makes an incredibly compelling moral case for the adoption of veganism. Nonetheless, this does not let non-stun slaughter off the hook. As already documented, there is a strong consensus amongst veterinarians and animal welfare scientists that non-stun slaughter poses a particularly serious challenge to animal welfare. The mere fact there are other methods of slaughter that also cause animals to suffer does not alter the justifiability of banning non-stun slaughter on welfare grounds. In the House of Lords case of $R$ (on the application of Countryside Alliance and others and others) $v$ Attorney General ${ }^{65}$ Baroness Hale found the ban on hunting mammals with dogs in England and Wales to be a proportionate interference with the claimants' rights to peaceful enjoyment of their possessions under article 1 of protocol 1 of the ECHR, noting that:

protecting wild animals from avoidable compromise to their welfare seems to me to fall well within the general interest and the means chosen to strike a fair balance. The fact that the same principles might have justified a wider ban does not mean that a narrower ban cannot be justified. ${ }^{66}$

\footnotetext{
63 Opinion of Advocate General Wahl, Case C-426/16, para 107.

${ }^{64}$ Ref. No. K52/13, para 8.2.2.

65 [2007] UKHL 52.

66 Ibid, para 129. See further $R$ (on the application of Petsafe Ltd) $v$ The Welsh Ministers, [2010] EWHC 2908 (Admin), para 65 (rejecting "selectivity" arguments against the proportionality of animal welfare measures).
} 
The same point applies, mutatis mutandis, in relation to a ban on non-stun in the absence of a wider ban on other forms of animal slaughter that cause suffering.

A second form of scepticism about a non-stun slaughter ban's capacity to advance animal welfare is that, if it were introduced, it would merely shift the problem elsewhere. As a ban on non-stun slaughter does not mean a prohibition on the consumption of non-stun slaughtered meat, the demand for it that would likely be met through increased reliance on imports, possibly sourced from countries with even lower animal welfare standards. Indeed, as the majority in Poland's Constitutional Tribunal pointed out, EU law not merely permits the import of non-stun slaughter meat into the territory of EU Member States but actually forbids Member States from prohibiting its entry into their territories if it comes from another Member State. ${ }^{67}$

In light of this, some may claim that a ban on non-stun slaughter would have a purely symbolic value, without actually improving the wellbeing of other creatures. However, as Charline de Coster states, National Authorities should not be deterred from pursuing domestic policies due to their lack of jurisdiction aboard (cited in van de Wiel 2017, p. 61). If every State adopted such a 'race to the bottom' logic, progress in improving animal welfare would be dramatically undermined. Accordingly, national efforts to improve animal welfare domestically must be regarded as legitimate end in themselves, and ought to be weighed against an interference with a qualified Convention right.

\section{Accompanied by "Relevant and Sufficient" Reasons}

The requirement that a restriction on a Convention right is accompanied by 'relevant and sufficient' reasons suggests that national authorities must make publically-available statements outlining the basis for the rights-restricting measures they enact. Such statements must both plausibly demonstrate that the measures are related to the stated goal (i.e. be relevant) and can plausibly and significantly contribute to the achievement of that goal (be sufficient).

When the minority in Cha'are Shalom stated that 'there is nothing to suggest that the ritual slaughterers employed by the applicant association do not comply... with the rules of hygiene' they were implicitly rejecting the idea that there were relevant and sufficient reasons to justify an interference with article 9 on the basis of protection of health. ${ }^{68}$ Animal welfare-based objections to non-stun slaughter will be easier to provide such reasons for, given the scientific evidence showing higher levels of suffering at the time of death for non-stun slaughter. Consequently, the relevant and sufficient reasons test should be readily satisfied for bans motivated by animal welfare.

\footnotetext{
67 Ref. No. K52/13, para 8.3.

68 Cha'are Shalom v France (n 18), Joint Dissenting Opinion of Judges Bratza, Fischbach, Thomassen, Tsata-Nikolovska, Pantiru, Levits and Traja, para 2.
} 


\section{Margin of Appreciation: Narrow or Wide?}

In this section we return to consider the issue of proportionality in more depth, focusing particularly on the question of the margin of appreciation afforded to States in relation to the issue of methods of animal slaughter and religious freedom. There are two key questions here: (1) would a total ban on non-stun slaughter for purposes of animal welfare give rise to a narrow or wide margin of appreciation? and, (2) having applied the wide or narrow margin of appreciation, would a total ban be proportionate under article $9(2)$ ?

\section{Wide or Narrow Margin of Appreciation?}

There is no definitive formula for establishing when and how the margin of appreciation should be applied. The complex interplay of variables involved makes it difficult to identify any exacting principles governing its application. However, the Court has issued some guidance concerning the relevant considerations for determining the breadth of the margin. In $S$ and Marper $v U K$ the Court stipulated:

A margin of appreciation must be left to the competent national authorities... The breadth of this margin varies and depends on a number of factors including the nature of the Convention right in issue, its importance for the individual, the nature of the interference and the object pursued by the interference. The margin will tend to be narrower where the right at stake is crucial to the individual's effective enjoyment of intimate or key rights... Where a particularly important facet of an individual's existence or identity is at stake, the margin allowed to the State will be restricted... Where, however, there is no consensus within the Member States of the Council of Europe, either as to the relative importance of the interest at stake or as to how best to protect it, the margin will be wider. ${ }^{69}$

A further criterion, not explicitly identified in $S$ and Marper but frequently used in the Court's jurisprudence is what Janneke Gerards calls the 'better placed criterion' (Gerards 2011, p. 110). According to this consideration, 'the court often leaves a wide margin of appreciation to the states because they are in a better position to assess the necessity, suitability or overall reasonableness of a limitation of fundamental rights' (ibid). We shall now consider three different criteria to determine whether the Court ought to apply a wide or narrow margin of appreciation to the issue of non-stun slaughter bans: the nature of the interference, the 'best placed criterion' and the extent of European consensus on the matter.

69 Application nos. 30562/04 and 30566/04, para 102. 


\section{The Nature of the Interference}

The Court has repeatedly stressed that the nature of the Convention right and its importance for the individual are of vital relevance to the scope of the margin of appreciation. Where the interference strikes at the 'core' of the right, the margin granted to states will be narrower. Conversely, where the interference is at the 'periphery' of the right, the margin will widen (ibid, 112). The 'core' components of a right can be understood to be those most closely related to the central values underpinning the Convention including 'the maintenance and promotion of the ideals and values of a democratic society and human dignity' (ibid).

Would a prohibition on non-stun slaughter constitute an interference with the core or periphery of the right to manifest one's religious beliefs? The right includes the ability to manifest religious beliefs through 'worship, teaching, practice and observance'. A prohibition on non-stun slaughter would prevent a form of religious practice relating to the preparation of food suitable for the observation of dietary laws. Concerning the ability of individuals to observe religious dietary laws, the court has adopted a fairly narrow margin of appreciation. For example, in cases involving prisoners the court has found that States have a positive duty to take reasonable and appropriate measures to ensure that suitable diets are available. Breaches of article 9 have been found for States' failures to provide vegetarian meals for Buddhist diets. ${ }^{70}$

However, a distinction can be drawn between requiring individuals to eat food that is deemed religiously impermissible (or otherwise go hungry) and preventing people from eating food that is religiously permissible but not mandatory. This was recognised by the former European Human Rights Commission in $X v$ the United Kingdom. ${ }^{71}$ The applicant was an orthodox Jewish prisoner who complained that he had not be provided with adequate kosher food. However, the Commission found no violation of article 9 because the applicant had access to a vegetarian Kosher diet that had been approved by the Jewish Visitation Committee and the Chief Rabbi. If a prohibition on non-stun slaughter led to no or restricted access to non-stun meat, this would not prevent individuals from eating a diet based on the observance of religious laws, it would merely prevent them from eating a portion of what is permissible under such a diet.

Furthermore, where a ban would not restrict access because such meat could be imported from another jurisdiction, the only interference would be a prohibition on people residing in that jurisdiction from directly participating in, or earning money from, non-stun slaughter themselves. Such activity is at the margins of the periphery of article 9. Although non-stun slaughter is a practice intimately linked to religion, there is no obligation for any individual to themselves take part in it and very few religious individuals do. In the present day context, non-stun slaughter is predominantly a commercial activity that produces products for religious people. While commercial activity is not per se excluded from the ambit of article 9 protection, ${ }^{72}$

\footnotetext{
70 Jakóbski v Poland, Application no. 18429/06, Vartic v Romania (no. 2), Application 14150/08.

71 Application no. 5947/72.

72 En l'affaire Cumhuriyetçi Eğitim Ve Kültür Merkezi Vakfı v Turkey, Application no. 32093/10.
} 


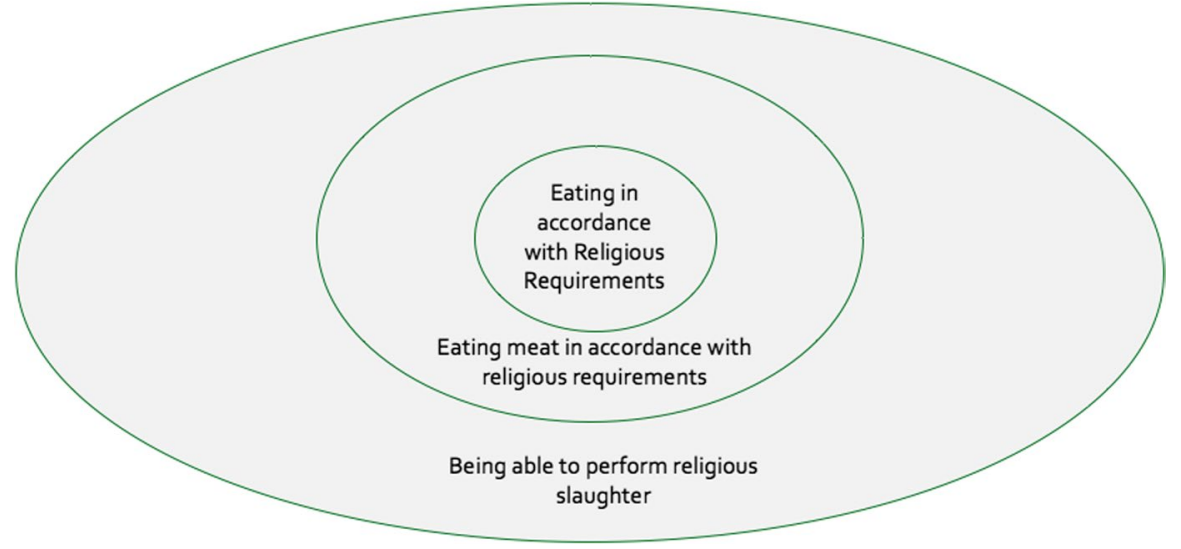

Fig. 1 The 'core-periphery' elements of article 9 in relation to observation of religious dietary laws

it ought to be regarded as the periphery of the article, just as commercial speech is peripheral to article $10 .^{73}$

Overall, the commercial nature of non-stun slaughter, coupled with the fact that it is not a mandated religious duty and that very few followers of religion directly partake in it, all count in favour of granting a wide margin of appreciation to States with regard to placing bans or restrictions on it (Fig. 1).

\section{Who is Best Placed to Make the Determination?}

The Court is more likely to leave a wide margin of appreciation to a Contracting State when they believe that the national authorities are in the best position to assess the necessity, suitability and reasonableness of a restriction on a Convention right.

In Cha'are Shalom the Court suggested that Contracting States ought to be afforded a wide margin of appreciation when it comes to the regulation of religious slaughter on the basis that it relates to the "establishment of the delicate relations between the Churches and the State. ${ }^{74}$ This somewhat opaque assertion presumably relates to the question of which religious bodies the State is obliged to grant licenses to. This consideration is not relevant in relation to general bans on non-stun slaughter because it would involve outlawing a certain practice rather than any particular religious groups participating in that practice.

There are however three reasons to think that the national authorities would be better placed than the Strasbourg Court in determining the appropriate balance between religious freedom and animal welfare in relation to non-stun slaughter bans. The first is that it involves a difficult balancing act to be struck between conflicting fundamental interests of religious freedom and animal welfare. The EtCHR is more

\footnotetext{
73 See e.g. Murphy v Ireland, Application no. 44179/98, para 67.

74 Cha'are Shalom v France (n 18), para 84.
} 
likely to be deferential to National authorities in cases that involve conflicts between important values (Gerards 2011, p. 111). Secondly, the issue involves technical and specialist expertise concerning animal welfare. In Friend \& Others $v U K^{75}$ the applicants argued that there was not sufficient evidence that hunting with dogs caused animals unnecessary suffering, making the ban on this practice a disproportionate interference with peaceful enjoyment of possessions under the article 1 of the protocol 1 of the Convention. However, the Court Stated that the margin of appreciation relating to legislation implementing social and economic policies was a wide one and that:

It also observes that the 2004 Act was preceded by extensive public debate, including the hearings conducted by the Burns Committee... In those circumstances, the Court is unable to accept that the House of Commons was not entitled to draw any conclusions as to the suffering of animals during hunting substantially undermined the reasons for the 2004 Act. The judgment that it was in the public interest to ban hunting was... pre-eminently one for the House of Commons to make. ${ }^{76}$

On a technical, scientific matter such as which measures are needed to protect animal welfare at the time of slaughter, the Court will grant States a wide margin of appreciation to States (Gerards, 2011, p. 111) to determine the appropriateness of restrictions on religious freedom in order to prevent forms of animal suffering deemed ethically objectionable.

A third reason why the Court is likely to view national authorities as being in the best position to judge the appropriateness of the interference in this case is because it pertains to the protection of 'morals'. Generally, the Court has held that,

by reason of their direct and continuous contact with the vital forces of their countries, State authorities are in principle in a better position than the international judge to give an opinion on the exact content of those moral and ethical requirements as well as on the "necessity" of a "restriction" intended to meet them. $^{77}$

This reasoning was used by the Court in Friend and Others to grant the UK a wide margin of appreciation in respect of restrictions placed on hunting for animal welfare reasons. ${ }^{78}$

In summary, because bans on non-stun slaughter involve the protection of morals, a balancing act to be struck between conflicting fundamental interests and technical expertise concerning animal welfare, it is clear that national authorities are in a better position than the Strasbourg Court to judge the appropriateness of interferences with article 9. This provides further support for a broad margin of appreciation before afforded to Contracting Parties.

\footnotetext{
75 Friend and Others $v$ UK (n 36).

76 Ibid, para 56.

77 Handyside v The United Kingdom (n 38), para 48.

78 Friend and Others $v U K$ (n 36) para 50.
} 


\section{Common European Consensus?}

Another important factor in determining the intensity of the Court's scrutiny of Contracting State interferences with fundamental rights is the extent to which there is common ground amongst $\mathrm{CoE}$ States pertaining to the protection of those rights. All else equal, the more common ground shared amongst States on the need to protect a right, the narrower the State's margin of appreciation will be for interferences with it. $^{79}$

It must be noted that the majority of CoE Member States-34 (72\%) permit the use of non-stun slaughter. The remaining $28 \%$ require prior stunning (17\%), post-cut stunning (9\%) and concurrent stunning (2\%) (Law Library of Congress 2018, p. 20). If one were to apply a strictly mathematical analysis to the question of European Consensus, one would have to conclude that there is significant agreement that the practice of non-stun slaughter for religious reasons falls within the scope of freedom to manifest one's religious beliefs.

However, the Court does not always determine the level of consensus in terms of simple majoritarian calculation. Sometimes "clear and uncontested evidence of a continuing international trend ${ }^{80}$ will suffice to narrow the margin of appreciation. However, what happens when the clear and international trend is moving in the direction of a narrower construal of a right? Does the margin of appreciation widen in such cases? Judge Pinto De Albuquerque evoked the notion of a 'continuing international trend' towards greater protection of animal life and welfare in his separate judgement in Herrmann $v$ Germany to suggest that animal-focused considerations could be invoked to justify limitations on Convention rights. ${ }^{81}$

Is there evidence of this 'continuing international trend' being reflected in relation to non-stun slaughter? Over recent decades Belgium, Demark, Estonia, Finland, Germany, the Netherlands, Slovenia and Switzerland either have banned non-stun slaughter or placed greater restrictions on it. In contrast, Latvia, Lithuania, Luxembourg and Poland have liberalised their laws to make it easier for religious communities to partake in ritual slaughter. In other countries, laws have remained largely unchanged for decades (Law Library of Congress 2018, pp. 2-19). In other words, while there has not been unidirectional travel amongst CoE States, there has nonetheless been a two to one ratio in favour of a more restrictive approach to non-stun slaughter.

A further reason to think that mere mathematical calculation will not always guide the ECtHR's view of European consensus was illustrated in SAS v France, where the Grand Chamber found that there was 'little common ground' on the issue

\footnotetext{
${ }^{79}$ S and Marper v UK (n 65), para 102.

${ }^{80}$ Goodwin v The United Kingdom, Application no. 28957/95, para 84.

81 'In negative terms, the safeguarding of the environment and animal life constitutes an implicit restriction on the exercise of human rights'. Herrmann v Germany (n 45), Partly concurring and partly dissenting opinion of Justice Pinto De Albuquerque.
} 
of bans on wearing full-face veils in public, even though France and Belgium were the only two CoE States to opt for such measures. ${ }^{82}$

One can question the plausibility of the Grand Chamber majority's overly broad assessment of European Common Consensus in SAS v France, but it is a further indication that the Court will not always not opt for a simple mathematical analysis of the Contracting Parties legal regimes. At any rate, as the above analysis has demonstrated, there is a far less stable European Consensus regarding non-stun slaughter than there is concerning the permissibility of wearing religious dress in public. This is further underscored by the subsidiarity afforded to states in relation to religious exemptions to the pre-stun requirement, demonstrating further recognition of a lack of consensus on the matter. This is all indicative that Contracting States will likely be granted a wide margin of appreciation with respect to this issue.

\section{Level of Scrutiny}

The preceding analyses of the nature of the interference with article 9, who is best placed to determine the reasonableness of that interference and what the present state of European Consensus is regarding it all point to States being afforded a wide margin of appreciation in relation to bans on non-stun slaughter.

A wide margin of appreciation results in a test of 'manifest unreasonableness' where the court will respect the legislature's judgement regarding a restriction on a right unless it is 'manifestly without reasonable foundation' (Gerards 2018, p. 499). This low bar for justifying an interference with a right would easily be satisfied in respect of a non-stun slaughter ban. As documented above, there is significant consensus amongst European veterinarians and welfare scientists that non-stun slaughter is sub-optimal from an animal welfare perspective so prohibiting it is eminently rational from the standpoint of advancing animal welfare.

Even if a narrow margin of appreciation were applied, it is argued that it would be relatively easy to find a non-stun slaughter ban proportionate. Where the court finds a narrower margin of appreciation it requires that a justification for a restriction be convincingly established and it strictly assesses the quality and persuasiveness of the justification advanced by the government. The Court may also demand that the aims of the restriction could not have been achieved by less restrictive means, and it strictly scrutinises the national decision-making processes (ibid).

The basis for justifying a ban on non-stun slaughter on animal welfare grounds has already been laid out above. But perhaps this objective can be attained through less restrictive measures, such as concurrent or immediate post-cut stunning as some European States have adopted (Joseph 2016). However, such a solution is not ideal from an animal welfare perspective (Brooman 2016). Whilst post-cut slaughter methods cause less suffering than the standard non-stun method, pre-stunning is clearly regarded as the gold standard by most animal welfare scientists, with

${ }^{82}$ SAS v France (n 42) para 156. 
concurrent and pre-stun methods regarded as second and third-best options. ${ }^{83}$ Others have proposed consumer-based solutions, such as better labelling of meat products (Brooman 2016). Again, whilst more transparent packaging could reduce some demand for non-stun products, market-focused approaches can only go so far (McMullen 2015). After all, they are dependent on the whims of individual consumers, whereas prohibitions create enforceable standards that all must observe.

As these alternative methods are sub-optimal from an animal welfare perspective, a Contracting Party's objectives would not be as effectively met if they were adopted instead. Provided a Contracting Party established a ban that did not place any further non-welfare related restrictions on ritual slaughter and preceded this with an adequate national decision-making process, informed by scientific opinion and inclusive of all affected stakeholders, it is likely that a total ban on non-stun slaughter could survive proportionality analysis even under a narrow margin of appreciation.

\section{Non-stun Slaughter and Discrimination}

The last issue to consider is whether a total ban on non-stun slaughter could be regarded as discriminatory under article 9 read in conjunction with article 14. Article 14 provides that the enjoyment of the rights and freedoms set out in the Convention 'shall be secured without discrimination on any ground such as... religion'.

Despite the preceding argument that article 9 itself would unlikely be violated by a ban on non-stun slaughter, this does not disbar the possibility that a breach could not be found in relation to article 9 conjoined with article 14. A finding of a breach of article 14 does not require a violation of the substantive Convention right concerned. ${ }^{84}$ Thus, a failure to afford equal treatment itself can be necessary, provided that the complaint falls within the broad ambit of a Convention right. ${ }^{85}$ As non-stun slaughter is a practice associated with religion, we must examine whether its prohibition would constitute discrimination.

To find a violation of article 14, two points must be established. The first is that discrimination occurred. This not merely includes direct discrimination where States treat persons in analogous situations differently, ${ }^{86}$ but also indirect discrimination where States 'fail to treat differently persons whose situations are significantly different'. ${ }^{87}$ Thus, where a general policy or measure has a disproportionately prejudicial effect on a particular group it may be considered discriminatory, notwithstanding whether it is accompanied by discriminatory intent.

\footnotetext{
${ }^{83}$ For example, The Farm Animal Welfare Council (2003) concluded their report with 'Slaughter without pre-stunning is unacceptable and the Government should repeal the current exemption' but that 'Until the current exemption which permits slaughter without pre-stunning is repealed, Council recommends that any animal not stunned before slaughter should receive an immediate post-cut stun' (paras 201 and 203).

84 Belgian Linguistic Case (No. 2), Application no. 2126/64, para 9.

85 Rasmussen v Denmark, Application no. 8777/79, para 29.

86 Belgian Linguistic Case (No. 2), (n 80), para 9.

87 Thlimmenos v Greece, Application No. 34369/97, para 44.
} 
A ban on non-stun slaughter would likely be regarded as a form of indirect discrimination, as such a ban would impose a uniform rule requiring that all animals killed in slaughterhouses are pre-stunned, thus failing to treat differently the different situation of religious groups who regard pre-stunning as contrary to their religious beliefs.

Secondly, the discriminatory measure must lack an 'objective and reasonable' justification. Such a justification will be found to be lacking if the measure does not pursue a 'legitimate aim' or if there is no 'reasonable relationship of proportionality' between the means employed and the aim sought to be realized. ${ }^{88}$ Whilst a ban on non-stun slaughter would have negative effects on individuals and businesses who engage in such practices for commercial purposes, this measure has an objective and reasonable justification for the reasons indicated in the previous sections.

\section{Conclusion}

This article has considered whether a ban on non-stun slaughter can be compatible with a State's obligations under the ECHR. It has argued that it can be, when done for reasons of protecting animal welfare. However, proposals for prohibitions nonetheless face formidable domestic challenges. There is of course significant political opposition to such bans stemming from a desire to maintain religious and cultural harmony. Moreover, against the backdrop of fears of rising anti-Semitism and Islamophobia, it is understandable that many will question the appropriateness of legal reform that disproportionately affects Jewish and Muslim communities.

At the same time, the welfare and rights of nonhuman animals also matter. Animals are amongst the most vulnerable members of society and are, at present, suffering terribly at the hands of humans. Stymying efforts to improve their condition in the name of human rights has an unpleasant ring to it, especially as there is now a growing awareness that human rights and animal rights are undergirded by the same or similar values and motivations (Cochrane 2013; Kymlicka 2018; Park and Valentino 2019).

To be sure, there are individuals, groups and even some political parties, who advocate bans on non-stun slaughter under the guise of concern for welfare to pursue a bigoted agenda against Muslims and Jews. Nevertheless, there are also plenty of animal welfare scientists and veterinarians who propose bans on non-stun slaughter who do not harbor such prejudices. In short, there are a variety of competing considerations at play in regulating non-stun slaughter. It is precisely because of this complexity that international courts such as the ECJ and the ECtHR ought to grant states a wide margin of appreciation on such matters. It ought to be the democratic process and domestic courts that have the final say on the matter.

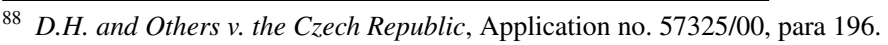




\section{Compliance with Ethical Standards}

Conflict of interest The author declare no conflict of interest.

Open Access This article is licensed under a Creative Commons Attribution 4.0 International License, which permits use, sharing, adaptation, distribution and reproduction in any medium or format, as long as you give appropriate credit to the original author(s) and the source, provide a link to the Creative Commons licence, and indicate if changes were made. The images or other third party material in this article are included in the article's Creative Commons licence, unless indicated otherwise in a credit line to the material. If material is not included in the article's Creative Commons licence and your intended use is not permitted by statutory regulation or exceeds the permitted use, you will need to obtain permission directly from the copyright holder. To view a copy of this licence, visit http://creativecommons.org/licen ses/by/4.0/.

\section{References}

Barrasso, Roberta, Elisabetta Bonerba, Edmondo Ceci, Rocco Roma, Antonio Alo, Anna Mottola, Celano Marchetti, Gatano Vitale, and Giancarlo Boozo. 2020. Evaluation of the Animal Welfare During Religious Slaughtering. Italian Journal of Food Safety 9(8387): 39-43.

Bilchitz, David. 2009. Moving Beyond Arbitrariness: The Legal Personhood and Dignity of Non-human Animals. South African Journal of Human Rights 29: 38-72.

Blattner, Charlotte. 2019. The Recognition of Animal Sentience by the Law. Journal of Animal Ethics 9(2): 121-136.

Bowman, Michael, Peter Davies, and Catherine Redgewell. 2010. Lyster's International Wildlife Law, 2nd ed, 672-699. Oxford: Oxford University Press.

Brooman, Simon. 2016. In Search of the Missing Ingredient: Religious Slaughter, Incremental Failure and the Quest for the Right to Know. Journal of Animal Ethics 6(2): 153-163.

BVA. 2019. Joint Call to End Non-Stun Slaughter. bva.co.uk. https://www.bva.co.uk/news-and-blog/newsarticle/joint-call-to-end-non-stun-slaughter/. Accessed 28 February 2020.

Cochrane, Alasdair. 2013. From Human Rights to Sentient Rights. Critical Review of International Social and Political Philosophy 16(5): 655-675.

Cohen, Jonathan. 2009. Kosher Slaughter, State Regulation of Religious Authorities, And the European Court of Human Rights. Intercultural Human Rights Review 4: 355-386.

DEFRA. 2019. Results of the 2018 FSA Survey into Slaughter Methods in England and Wales. https://asset s.publishing.service.gov.uk/government/uploads/system/uploads/attachment_data/file/778588/slaug hter-method-survey-2018.pdf. Accessed 19 May 2020.

Downing, Emma. 2015. Religious Slaughter of Animals. House of Commons Library SN07108 SES: 1-28.

EFSA. 2004. Opinion of the Scientific Panel on Animal Health and Welfare on a Request from the Commission Related to Welfare Aspects of the Main Systems of Stunning and Killing the Main Commercial Species of Animals. The EFSA Journal 45: 1-29.

Eisen, Jessica. 2017. Animals in the Constitutional State. International Journal of Constitutional Law 15(4): 909-954.

EU. 2016. Attitudes of Europeans towards Animal Welfare. Special Eurobarometer 442.

Evans, Carolyn. 2001. Freedom of Religion under the European Convention on Human Rights, 160. Oxford: Oxford University Press.

Evans, Malcolm. 1997. Religious Liberty and International Law in Europe, 328. Cambridge: Cambridge University Press.

Farm Animal Welfare Council. 2003. FAWC Report on the Welfare of Farmed Animals at Slaughter or Killing, Part 1, Red Meat Animals. https://www.gov.uk/government/publications/fawc-report-on-the-welfa re-of-farmed-animals-at-slaughter-or-killing. Accessed 27 February 2020.

Feinberg, Joel. 1992. The Rights of Animals and Unborn Generations. In Rights, Justice and the Bounds of Liberty, ed. Joel Feinberg. Princeton: Princeton University Press.

Gerards, Janneke. 2011. Pluralism, Deference and the Margin of Appreciation Doctrine. European Law Journal 17(1): 80-120.

Gerards, Janneke. 2013. How to Improve the Necessity Test of the European Court of Human Rights. International Journal of Constitutional Law 11(2): 466-490. 
Gerards, Janneke. 2018. Margin of Appreciation and Incrementalism in the Case Law of the European Court of Human Rights. Human Rights Law Review 18(3): 495-515.

Global Animal Law. Database for Council of Europe and EU. Globalanimallaw.org. https://www.globalanim allaw.org/database/europe.html. Accessed 26 February 2020.

Grandin, Temple, and Joe Regenstein. 1994. Religious Slaughter and Animal Welfare: A Discussion for Meat Scientists. Meat Focus International 3: 115-123.

Greer, Stephen. 1997. The Exceptions to Articles 8 to 11 of the European Convention on Human Rights, 35. Strasbourg: Council of Europe Publishing.

Gregory, Raj. 1996. Welfare Implications of Gas Stunning of Pigs 2-Stress of Induction of Anaesthesia. Animal Welfare 5: 71-78.

Haupt, Claudia. 2007. Free Exercise of Religion and Animal Protection: A Comparative Perspective on Ritual Slaughter. The George Washington International Law Review 39(839-886): 885.

Henrard, Kristin. 2016. Duties of Reasonable Accommodation on Grounds of Religion in the Jurisprudence of the European Court of Human Rights: A Tale of (Baby) Steps Forward and Missed Opportunities. International Journal of Constitutional Law 14(4): 961-983.

Institute for Jewish Policy Research. 2014. Jews in the United Kingdom in 2013: Preliminary Findings from the National Jewish Community Survey. https://pearsfoundation.org.uk/wp-content/uploads/2018/06/ JPR_Jews_in_the_UK_in_2013_NJCS_preliminary_findings.Feb_.-2014.pdf. Accessed 19 May 2020.

Joseph, Anna. 2016. Going Dutch: A Model for Reconciling Animal Slaughter Reform with the Religious Freedom Restoration Act. Journal of Animal Ethics 6(2): 135-152.

Kymlicka, Will. 2018. Human Rights Without Human Supremacism. Canadian Journal of Philosophy 48(6): 763-792.

Law Library of Congress. 2018. Legal Restrictions on Religious Slaughter in Europe. https://www.loc.gov/ law/help/religious-slaughter/religious-slaughter-europe.pdf. Accessed 28 February 2020.

Lerner, Pablo, and Alfredo Mordechai Rabello. 2006. The Prohibition of Ritual Slaughtering (Kosher Shechita and Halal) and Freedom of Religion of Minorities. Journal of Law and Religion 22(1): 1-62.

McMullen, Steven. 2015. Is Capitalism to Blame? Animal Lives in the Marketplace. Journal of Animal Ethics 5(2): 126-134.

Mellor, David, Troy Gibson, and Craig Johnson. 2009. A Re-evaluation of the Need to Stun Calves Prior to Slaughter by Ventral-Neck Incision: An Introductory Review. New Zealand Veterinary Journal 57(2): 77-85.

Millis, Joe. 2019. Shechita UK Anger as Animal Welfare Groups, Including the RSPCA, Demand Pre-Stunning. Jewish News. https://jewishnews.timesofisrael.com/shechita-uk-attacks-animal-welfare-group s-demand-for-pre-stunning/. Accessed 28 February 2020.

Muslim Council of Britain. 2015. The Muslim Council of Britain Calls on the BVA to "Get Real" on Animal Welfare. mcb.org.uk https://mcb.org.uk/press-releases/muslim-council-britain-calls-bva-get-real-anima 1-welfare/. Accessed 28 February 2020.

Park, Yon Soo, and Benjamin Valentino. 2019. Animals are People Too: Explaining Variation in Respect for Animal Rights. Human Rights Quarterly 41(1): 39-65.

Peters, Anne. 2017. Introduction to Symposium on Global Animal Law (Part I): Animals Matter in International Law and International Law Matters for Animals. AJIL Unbound. https://doi.org/10.1017/ aju.2017.70.

Peters, Anne. 2019. Religious Slaughter and Animal Welfare Revisited: CJEU, Liga van Moskeeën en islamitische Organisaties Provincie Antwerpen. Canadian Journal of Comparative and Constitutional Law 5(1): 269-297.

Schabas, William. 2015. The European Convention on Human Rights: A Commentary, 437. Oxford: Oxford University Press.

Shields, S.J., and A.B. Raj. 2010. A Critical Review of Electrical Water-Bath Stun Systems for Poultry Slaughter and Recent Developments in Alternative Technologies. Journal of Applied Animal Welfare Science 13(4): 281-299.

Sunstein, Cass. 2000. Standing for Animals (with Notes on Animal Rights). UCLA Law Review 47: 1333-1368.

van de Wiel, Cheryl-Lynn. 2017. Freedom of Religion Versus Animal Welfare: The Compatibility of the Flemish Ban on Unstunned Slaughter with Freedom of Religion. http://arno.uvt.n1/show.cgi?fid=14596 7. Accessed 27 February 2020.

Wax, Eddy. 2019. Belgium Tests EU Rules on Halal and Kosher. https://www.politico.eu/article/belgiumbecomes-eu-test-case-on-halal-and-kosher-slaughter-religious-freedoms-animal-welfare/. Accessed 28 February 2020. 
Zivotofsky, Ari. 2012. Government Regulations of Shechita (Jewish Religious Slaughter) in the Twenty-First Century: Are They Ethical? Journal of Agricultural Environmental Ethics 25: 747-763.

Zoethout, Carla. 2013. Ritual Slaughter and the Freedom of Religion: Some Reflections on a Stunning Matter. Human Rights Quarterly 35(3): 651-668.

Publisher's Note Springer Nature remains neutral with regard to jurisdictional claims in published maps and institutional affiliations. 